\title{
Which Organizational Culture Moves towards Organizational Excellency
}

\author{
Ali Sadeghi Gogheri ${ }^{1}$, Khaled Nawaser ${ }^{2}$, Seyed Mahdi Vesal ${ }^{3}$, Asghar Afshar Jahanshahi ${ }^{4} \&$ Roshan Kazi $^{2}$ \\ ${ }^{1}$ Department of management, Islamic Azad University, Sirjan Branch, Iran \\ ${ }^{2}$ Allana Institute of Management Sciences (AIMS), University of Pune, India \\ ${ }^{3}$ Department of Management, University of Nooretouba, Iran \\ ${ }^{4}$ Department of Industrial \& Systems Engineering, Pontificia Universidad Catolica de Chile, Chile \\ Correspondence: Khaled Nawaser, Allana Institute of Management Sciences (AIMS), University of Pune, India. \\ Tel: 98-937-970-6560. E-mail: khalednawaser56@gmail.com
}

Received: April 18, 2013 Accepted: June 13, 2013 Online Published: August 30, 2013

doi:10.5539/ass.v9n11p221 URL: http://dx.doi.org/10.5539/ass.v9n11p221

\begin{abstract}
The present research paper studies "the relationship of types of culture and the execution of organizational excellencies based on the EFQM model in government organizations" in which its results are analyzed and interpreted generally. The required data for this research have been collected from 311 questionnaires containing questions of personal details and questions about the research hypotheses. In this study, the descriptive statistics methods were used to describe the data such as frequency tables, charts, and the frequency histogram for the major and minor variables. Moreover, after Chi-Square Test (independence) which was used to test the independence of variables, Kendall and Spearman correlation tests were used to determine the correlation. In this study, all statistical analyses were performed using computer and SPSS software.
\end{abstract}

Keywords: organizational culture, organizational excellency, European foundation of quality management (EFQM)

\section{Introduction}

Studies have shown that the commitment of the members towards organizational culture values is an essential mechanism to increases productivity and to move towards excellency. But the relationship between organizational culture and excellency is more complex than can be explained by a simple relationship. Some experts of management and organization believe that in order to affect the organizational performance and excellency the organizational culture should be a strong culture (Matin, 1998). A strong culture increases the commitment to the organization and increases the alliance employees' goals and objectives of the organization. This is an important factor for increasing productivity and ultimately for increasing the level of excellency of organization.

The strong values of organizational culture may affect performance, productivity and the rate of excellency at the first step but if people's cultural and commitment controls of the elements of organizational culture are severe and increasing, it will creates some preventions from cultural methods and therefore the organization will not be able to change its behavioral methods in tune with environment changes. This will have a negative effect on productivity and the rate of excellency because the development of mutual understandings may have significant effect on control process via forming the thoughts and commitments of members to each other. But these mutual understandings may reduce talent for environmental learning. Even, mutual understandings may be aroused as mutual deception.

Studies show that "culture" can be counted as capital with positive factor or as a debt. Culture is considered as the capital when common values lead to ease of communication, good decision making, increased motivation, coordination and commitment of employees towards the organization and its goals (Mamizadeh, 1997). Therefore, the organization productivity will be improved. "But sometimes values of the strong culture may prevent the necessary changes in the organization in tune with environmental conditions and needs" and will lead to deduction of the level of excellency. 


\section{Literature Review}

\subsection{Organizational Culture}

The plans of evaluation and performance management should be based on continuous improvement, not on the blame-based culture. The most important principle of performance is to ensure that this evaluation system should be based on a culture of continuous improvement rather than blame in order to ensure service users. If the performance of a particular index is lower than average rate, it is necessary to identify causes of errors and how to deal with it in the future. If management sector wants to blame someone or a section, that will be unfair and an obstacle for productivity (Moullin, 2004).

Studies show that culture does affect goals, strategies, individual behavior, organizational performance, motivation; job satisfaction, creativity and innovation, decision making, the participation rate of employees in the related affairs, dedication and commitment, hard work and anxiety levels. Studies also indicate that the excellent and successful organizations have a strong culture and are effective (BagheriZadeh, 1996).

By the expansion and complexity of objectives, processes and organizational structure in the arena of competition for survival can continue their expectations and demands in the competition, organizations of customers in order to respond to the demands and expectations of customers and stakeholders. In addition, they should be responsive to profitability and wealth creation as a key indicator according to organizational excellence. Managers are concerned about the output and results of their activities in any organization and seek strategies and solutions for performance improvement of organization. They usually try to monitor and follow on the activities of their corresponding through performance measurement systems. (Daft, 2009) divided organizational culture into four parts in a classification proportionally between business and work strategies which are summarized as:

Flexible Culture: a culture which can be determined by focus on the external environment through flexibility and change to respond to customer needs.

Mission Culture: the culture emphasizes on a clear prospective of the objectives of organization in order to achieve these goals.

Participative Culture: the focus of this culture is on the involvement and participation of individuals and members of environmental organizations and on the expectation of an environment that is changing quickly.

Bureaucratic Culture: this culture has an internal focus and a sustainable direction for a stable environment.

\subsection{European Foundation of Quality Management (EFQM)}

EFQM organizational excellency model is a complete and total-oriented approach which provides the assurance of long-term success. This is a self-assessment tool for current health diagnosis of organization. Through self-assessment of the organization, it can effectively establish balance through opportunities, allocation of resources and real productive business applications. Researches show that application of the pre-eminent model in private-sectors of organizations is more successful than in public sectors of organizations (Jahanshahi et al., 2012).

In addition, the other related researches show that almost 60 percent of European companies make use of this model for the self-evaluation purpose (Eskildsen, 2002)

The EFQM model includes five enabling criteria:

1) Leadership (100 points)

2) Policy and Strategy (80 Points)

3) Staff (90 points)

4) Partnerships and resources (90 points)

5) Processes (140 points)

It also includes four criteria of results:

1) Customer results (200 points)

2) Results of staff(90points)

3) Results of society (60 points)

4) Key results of performance (150 points) (Jahanshahi, et al, 2012).

The excellence or pre-eminent model is a framework of nine criteria which assumes that there are different 
approaches to achieve the desired excellence (Ghobadian \& Woo, 1996). The framework of this model is shown in the figure 1 below.

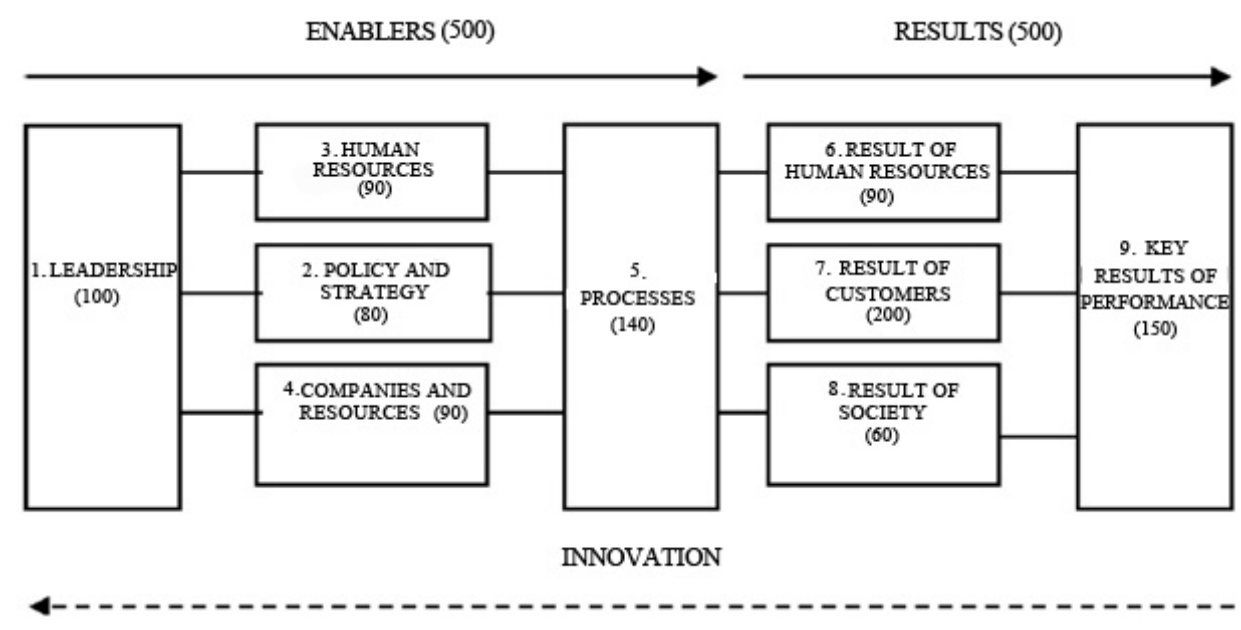

Figure 1.

Those organizations that institutionalized a principle of continuous improvement and value in their thinking, always interested in identifying and understanding their position and status because they properly found that they can make decision easily to achieve their goals in future. To do so, they are always interested to evaluate themselves because it is thought that if we know how we are, we will decide how we are planning for the future? (Najmi \& Hosseini, 2006).

What organizations are facing as a big question is that by what means and how we can all identify strengths and areas for improvement to be ready for their successful performance in future competitions through a comprehensive study of different cases? (Jafari Ghoshchi, 2005). In this regard, the pre-eminent organization model or EFQM model is known as a powerful tool for identifying strengths and areas of significant improvement which can define the organizational management system as a coherent and systematic framework that can be intertwined and can assists managers in the application of management techniques (Gerami \& Noralizadeh, 2006).

Regarding the fact that each organization has its own culture which includes a particular series of values and beliefs to induce employees and it can be effective on method performance and quality of staff work. Furthermore, the EFQM Excellence model or one of models of the quality of European culture on which dominant culture on organizations can work on it. So the basic question of this research is that what is the dominant culture in public organizations in Kerman city and to examine whether there is a relation between the implementation of the EFQM model of excellence or excelled in accordance with organizational culture or not?

\subsection{Related Results to General Research Variables or Demographic}

- The understudied population includes 330 people in which 311 people of them responded to questionnaires. The remained 19 persons who have not responded to the questionnaire were 6 percent of the total respondents that they were not significant.

- Considering age, 59 persons (23.7\%) are 31 years old, 122 persons (49\%) are 31-40 years old and 68 persons (27.3\%) are above 40 years old. Furthermore, 62 persons did not specify their age.

- Regarding gender, 189 individuals (62.4\%) are males and 114 persons (37.6\%) are women. In addition, eight of employees did not specify their gender.

- Regarding the level of education, 48 persons (7.15\%) possess diploma or lower degree holders and 62 persons (3.20\%) are A.A holders and 157 persons (3.51\%) are B.A. holders and 35persons (4.11\%) are M.A. holders and 4 persons (3.1\%) are Ph.D. holders and 5 of participants did not specify their education level.

- Regarding the records of service, 45 persons (6.19\%) have less than 6 years of experience, 39 persons (17\%) have 6-10 years, 46 persons have $15-11$ year, 54 persons (5.23\%) have $20-16$ years and 22 persons $(6.9 \%)$ have 
25-21 years of experience. Furthermore, 24 patients (4.10\%) have served more than 25 years. In addition, 81 subjects did not specify the status of their service.

- Considering the type of organization, 136 cases (42\%) work in cultural, educational and research organizations and 194 persons (59\%) work in productive and basic organizations.

\subsection{Study of the Rate of (Mean Score) the Organizational Dominant Culture in Different Organizations in Kerman City}

In general, cultures were available in organizations include; flexible culture, bureaucratic culture, the culture of mission and participative culture. The highest and lowest scores respectively go to education and training and Islamic propagation organizations as far as the participative culture is concerned. Regarding the flexible culture, respectively martyr foundation and the Islamic propagation organization is dedicated. Regarding mission culture, respectively, labor and social affairs and the Islamic propagation organizations are concerned. Regarding the bureaucratic culture, respectively, agriculture Labor and social affairs organizations are concerned. In total, the highest and lowest scores of organizational culture, respectively, go for martyr foundation and Islamic propagation organizations.

Table 1. Comparison of the scores of dominant culture and organizational culture in each of the organizations

\begin{tabular}{lllll}
\hline Organization & \multicolumn{2}{l}{ Participative Culture } & $\begin{array}{c}\text { Flexibility } \\
\text { Culture }\end{array}$ & \multicolumn{2}{c}{ Mission Culture } & $\begin{array}{l}\text { Bureaucratic } \\
\text { Culture }\end{array}$ \\
\hline Labor and Social Affairs & 3.17 & 3.33 & 3.83 & 3.89 \\
Education and Training & 3.71 & 3.76 & 3.78 & 3.61 \\
Martyr Foundation & 3.15 & 3.88 & 3.54 & 3.66 \\
Cultural Heritage & 3.43 & 3.42 & 3.38 & 3.40 \\
Rural Cooperation & 3.27 & 3.73 & 3.826 & 3.45 \\
Housing and Urban Development & 2.95 & 3.00 & 3.28 & 3.30 \\
Islamic Propagation & 2.50 & 2.78 & 3.06 & 3.67 \\
Trade & 3.20 & 3.73 & 3.57 & 3.55 \\
Welfare & 2.83 & 3.48 & 3.54 & 3.75 \\
Finance & 3.17 & 3.50 & 3.08 & 3.33 \\
Industry and Mines & 3.19 & 3.50 & 3.25 & 3.38 \\
Agriculture & 2.83 & 3.30 & 3.13 & 3.20 \\
Total & 3.10 & 3.47 & 3.41 & 3.45 \\
\hline
\end{tabular}

\subsection{Evaluation of the Rate of (Mean Score) Organizational Excellency Performance Based on the EFQM Model and Its Components}

According to the data analysis, average score of implementing Organizational excellency Performance based on the model is calculated as 419.1 in all organizations. The most excellent organization of Kerman city goes for education and training organization and the lowest excellency performance goes for bureaucratic culture and the Islamic propagation organization. The obtained scores of large and small indicators of excellence, respectively, include: policy and strategy, customer results, leadership, participations and resources, processes, employees, society results, key results and personnel results. 
Table 2. Comparison of scores of organizational culture and organizational excellency performance based on the EFQM model in each of the organizations

\begin{tabular}{|c|c|c|c|c|c|c|c|c|c|c|c|}
\hline $\begin{array}{l}\text { Organiz } \\
\text { ation }\end{array}$ & $\begin{array}{l}\text { Leader } \\
\text { ship }\end{array}$ & $\begin{array}{l}\text { Polic } \\
\mathrm{y} \\
\text { and } \\
\text { Strat } \\
\text { egy }\end{array}$ & $\begin{array}{l}\text { Perso } \\
\text { nnel }\end{array}$ & $\begin{array}{l}\text { Participa } \\
\text { tions } \\
\text { and } \\
\text { Resourc } \\
\text { es }\end{array}$ & $\begin{array}{l}\text { Proce } \\
\text { sses }\end{array}$ & $\begin{array}{l}\text { Costu } \\
\text { mers } \\
\text { Result } \\
\text { s }\end{array}$ & $\begin{array}{l}\text { Perso } \\
\text { nnel } \\
\text { Result } \\
\text { s }\end{array}$ & $\begin{array}{l}\text { Soci } \\
\text { ety } \\
\text { Res } \\
\text { ults }\end{array}$ & $\begin{array}{l}\text { Key } \\
\text { Res } \\
\text { ults }\end{array}$ & $\begin{array}{l}\text { Perform } \\
\text { ance } \\
\text { Excelle } \\
\text { ncy }\end{array}$ & $\begin{array}{l}\text { Domina } \\
\text { nt } \\
\text { Culture }\end{array}$ \\
\hline $\begin{array}{l}\text { Labor } \\
\text { and } \\
\text { Social } \\
\text { Affairs }\end{array}$ & 43.00 & $\begin{array}{l}42.4 \\
7\end{array}$ & 36.27 & 40.69 & 48.93 & 34.73 & 51.48 & $\begin{array}{l}41.7 \\
8\end{array}$ & $\begin{array}{l}33.8 \\
3\end{array}$ & 39.56 & $\begin{array}{l}\text { Bureauc } \\
\text { ratic }\end{array}$ \\
\hline $\begin{array}{l}\text { Educati } \\
\text { on and } \\
\text { Training }\end{array}$ & 56.79 & $\begin{array}{l}52.3 \\
5\end{array}$ & 51.66 & 53.08 & 51.69 & 52.42 & 58.77 & $\begin{array}{l}53.2 \\
8\end{array}$ & $\begin{array}{l}47.8 \\
4\end{array}$ & 52.01 & Mission \\
\hline $\begin{array}{l}\text { Martyrs } \\
\text { Foundat } \\
\text { ion }\end{array}$ & 51.33 & $\begin{array}{l}47.0 \\
3\end{array}$ & 47.68 & 47.20 & 48.09 & 44.82 & 51.70 & $\begin{array}{l}48.0 \\
8\end{array}$ & $\begin{array}{l}46.4 \\
0\end{array}$ & 44.95 & Flexible \\
\hline $\begin{array}{l}\text { Cultural } \\
\text { Heritage }\end{array}$ & 58.08 & $\begin{array}{l}57.1 \\
5\end{array}$ & 41.49 & 48.64 & 52.67 & 51.36 & 44.57 & $\begin{array}{l}49.7 \\
1\end{array}$ & $\begin{array}{l}48.0 \\
1\end{array}$ & 53.38 & $\begin{array}{l}\text { Particip } \\
\text { ative }\end{array}$ \\
\hline $\begin{array}{l}\text { Rural } \\
\text { Coopera } \\
\text { tion }\end{array}$ & 42.35 & $\begin{array}{l}47.5 \\
9\end{array}$ & 39.29 & 38.29 & 39.38 & 42.82 & 36.21 & $\begin{array}{l}39.4 \\
0\end{array}$ & $\begin{array}{l}42.3 \\
0\end{array}$ & 23.15 & Mission \\
\hline $\begin{array}{l}\text { Housing } \\
\text { and } \\
\text { Urban } \\
\text { Develop } \\
\text { ment }\end{array}$ & 35.89 & $\begin{array}{l}44.1 \\
2\end{array}$ & 42.81 & 35.29 & 39.46 & 41.27 & 36.43 & $\begin{array}{l}38.1 \\
9\end{array}$ & $\begin{array}{l}34.5 \\
1\end{array}$ & 38.78 & $\begin{array}{l}\text { Bureauc } \\
\text { ratic }\end{array}$ \\
\hline $\begin{array}{l}\text { Islamic } \\
\text { Propaga } \\
\text { tion }\end{array}$ & 17.64 & $\begin{array}{l}12.8 \\
6\end{array}$ & 12.49 & 15.98 & 10.29 & 4.42 & 6.96 & $\begin{array}{l}10.9 \\
7\end{array}$ & $\begin{array}{l}11.5 \\
9\end{array}$ & 7.37 & $\begin{array}{l}\text { Bureauc } \\
\text { ratic }\end{array}$ \\
\hline Trade & 45.14 & $\begin{array}{l}48.1 \\
6\end{array}$ & 41.03 & 45.62 & 48.88 & 46.83 & 46.83 & $\begin{array}{l}45.1 \\
5\end{array}$ & $\begin{array}{l}39.9 \\
1\end{array}$ & 45.29 & Flexible \\
\hline Welfare & 44.33 & $\begin{array}{l}47.8 \\
1\end{array}$ & 44.38 & 47.04 & 46.33 & 38.90 & 47.66 & $\begin{array}{l}45.2 \\
7\end{array}$ & $\begin{array}{l}44.1 \\
7\end{array}$ & 44.36 & $\begin{array}{l}\text { Bureauc } \\
\text { ratic }\end{array}$ \\
\hline Finance & 57.70 & $\begin{array}{l}55.4 \\
6\end{array}$ & 52.10 & 41.53 & 38.80 & 23.13 & 38.15 & $\begin{array}{l}40.5 \\
8\end{array}$ & $\begin{array}{l}34.7 \\
9\end{array}$ & 24.00 & Flexible \\
\hline $\begin{array}{l}\text { Industry } \\
\text { and } \\
\text { Mines }\end{array}$ & 39.85 & $\begin{array}{l}44.7 \\
3\end{array}$ & 43.71 & 53.51 & 51.24 & 40.79 & 52.97 & $\begin{array}{l}46.7 \\
7\end{array}$ & $\begin{array}{l}38.3 \\
1\end{array}$ & 56.23 & Flexible \\
\hline $\begin{array}{l}\text { Agricult } \\
\text { ure }\end{array}$ & 32.63 & $\begin{array}{l}37.2 \\
3\end{array}$ & 35.62 & 32.93 & 33.29 & 27.90 & 35.95 & $\begin{array}{l}33.6 \\
9\end{array}$ & $\begin{array}{l}32.6 \\
6\end{array}$ & 35.40 & Flexible \\
\hline Total & 42.96 & $\begin{array}{l}44.6 \\
6\end{array}$ & 41.61 & 41.86 & 42.66 & 38.96 & 43.79 & $\begin{array}{l}41.9 \\
1\end{array}$ & $\begin{array}{l}39.1 \\
5\end{array}$ & 41.50 & Flexible \\
\hline
\end{tabular}

It is worth mentioning that the numbers in the above table have been calculated from 100 points

\subsection{Testing of Hypotheses}

2.6.1 There Is a Relationship between Participative Culture and Organizational Excellency Performance Based on EFQM Model

$\mathbf{H}_{0}$ : There is no relationship between participative culture and organizational excellency performance based on EFQM model. 
$\mathbf{H}_{1}$ : There is a relationship between participative culture and organizational excellency performance based on EFQM model.

Regarding the fact that the levels of significance were significantly less than 0.05 in both cases, therefore, the hypothesis $\mathrm{H}_{0}$ is rejected and this means that there is a significant relationship between participative culture and the EFQM excellence model. Kendall and Spearman correlation coefficients are calculated as 0.505 and 0.651 between two variables respectively. These points are also reliable regarding the scatter plot in the figure.

Table 3. Correlation test between participative culture and organizational quality excellency performance based on EFQM model

\begin{tabular}{lllllll}
\hline \multicolumn{3}{l}{ Karticipative Culture } & \multicolumn{3}{l}{ Spearman } \\
\hline $\begin{array}{l}\text { Kendall } \\
\text { of }\end{array}$ & Correlation & Significance & Frequency & Correlation & Significance & Frequency \\
$\begin{array}{l}\text { Organizational } \\
\text { Excellency }\end{array}$ & 0.505 & 0.000 & 298 & 0.651 & 0.000 & 298 \\
\hline
\end{tabular}

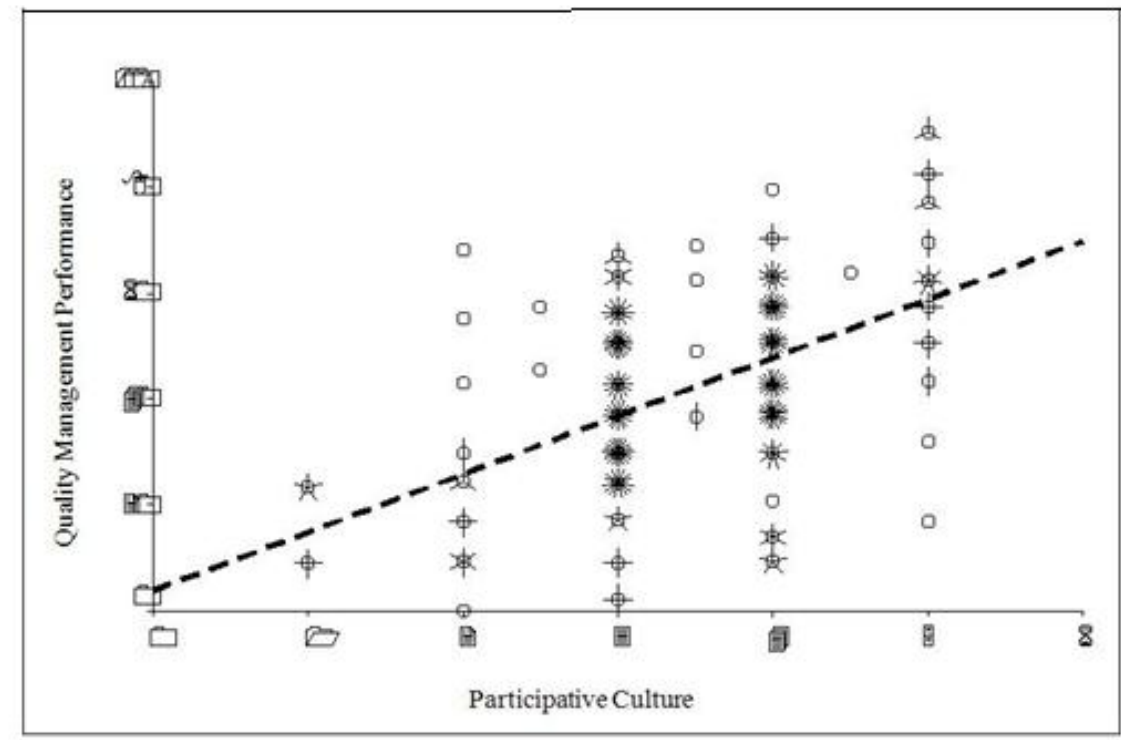

Figure 2. Scatter plot and regression line based on the EFQM model of excellence against participative culture

2.6.2 There Is a Relationship between Flexibility Culture and Organizational Excellency Performance Based on EFQM Model

$\mathbf{H}_{\mathbf{0}}$ : There is no relationship between flexibility culture and organizational excellency performance based on EFQM model.

$\mathbf{H}_{1}$ : There is a relationship between flexibility culture and organizational excellency performance based on EFQM model.

Regarding the fact that the levels of significance were significantly less than 0.05 in both cases, therefore, the hypothesis $\mathrm{H}_{0}$ is rejected and this means that there is a significant relationship between organizational culture and the EFQM excellence model. Kendall and Spearman correlation coefficients are calculated as 0.371 and 0.466 between two variables respectively. These points are also reliable regarding the scatter plot in the figure. 
Table 4. Correlation test between flexibility culture and organizational excellency performance based on EFQM model

\begin{tabular}{llllllll}
\hline & \multicolumn{3}{l}{ Flexibility Culture } & & & \\
& Kendall & & & & \\
\hline $\begin{array}{l}\text { Performance } \\
\text { Organizational }\end{array}$ & of & Correlation & Significance & Frequency & Correlation & Significance & Frequency \\
Excellency & 0.371 & 0.000 & 298 & 0.466 & 0.000 & 298 \\
\hline
\end{tabular}

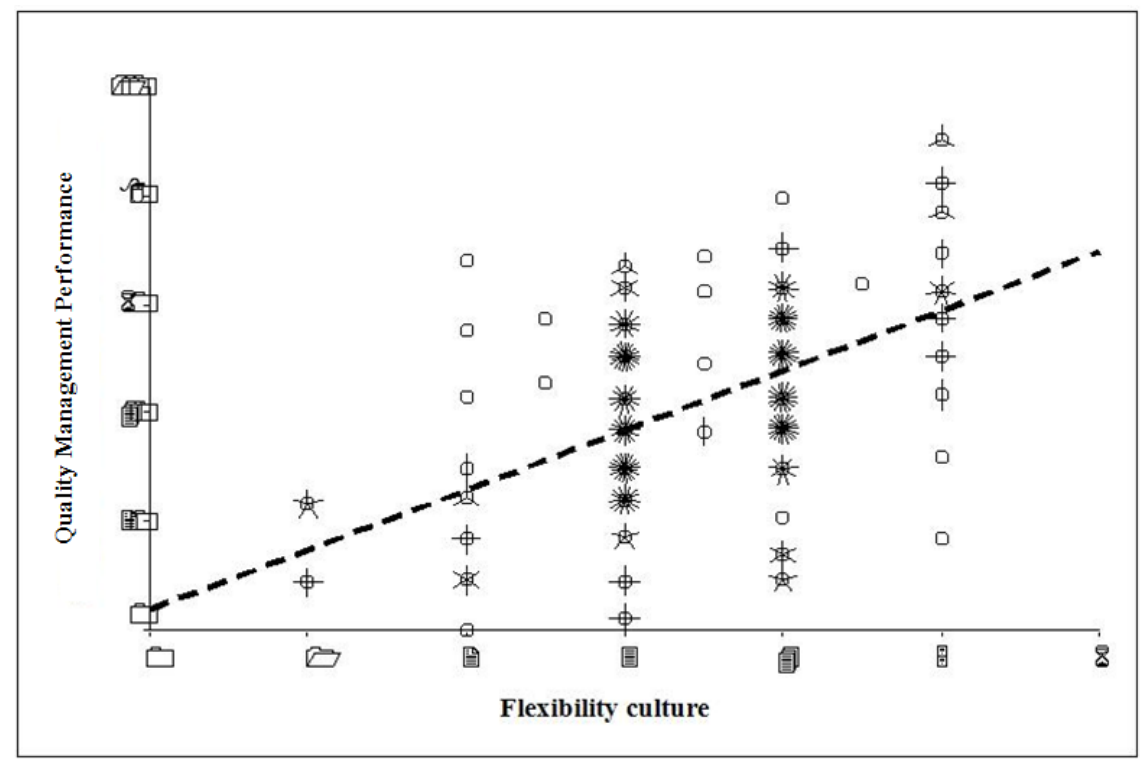

Figure 3. Scatter plot and regression line based on the EFQM model of excellence against flexible culture

2.6.3 There Is a Relationship between Mission Culture and Organizational Excellency Performance Based on EFQM Model

$\mathbf{H}_{\mathbf{0}}$ : There is no relationship between mission culture and organizational excellency performance based on EFQM model.

$\mathbf{H}_{1}$ : There is a relationship between mission culture and organizational excellency performance based on EFQM model.

Regarding the fact that the levels of significance were significantly less than 0.05 in both cases, therefore, the hypothesis $\mathrm{H}_{0}$ is rejected and this means that there is a significant relationship between mission culture and the EFQM excellence model. Kendall and Spearman correlation coefficients are calculated as 0.337 and 0.442 between two variables respectively. These points are also reliable regarding the scatter plot in the figure.

Table 5. Correlation test between mission culture and organizational excellency performance based on EFQM model

\begin{tabular}{|c|c|c|c|c|c|c|}
\hline & \multicolumn{6}{|c|}{ Mission Culture } \\
\hline & Kendall & & & Spearman & & \\
\hline Performance & Correlation & Significance & Frequency & Correlation & Significance & Frequency \\
\hline $\begin{array}{l}\text { Organizational } \\
\text { Excellency }\end{array}$ & 0.337 & 0.000 & 298 & 0.442 & 0.000 & 298 \\
\hline
\end{tabular}




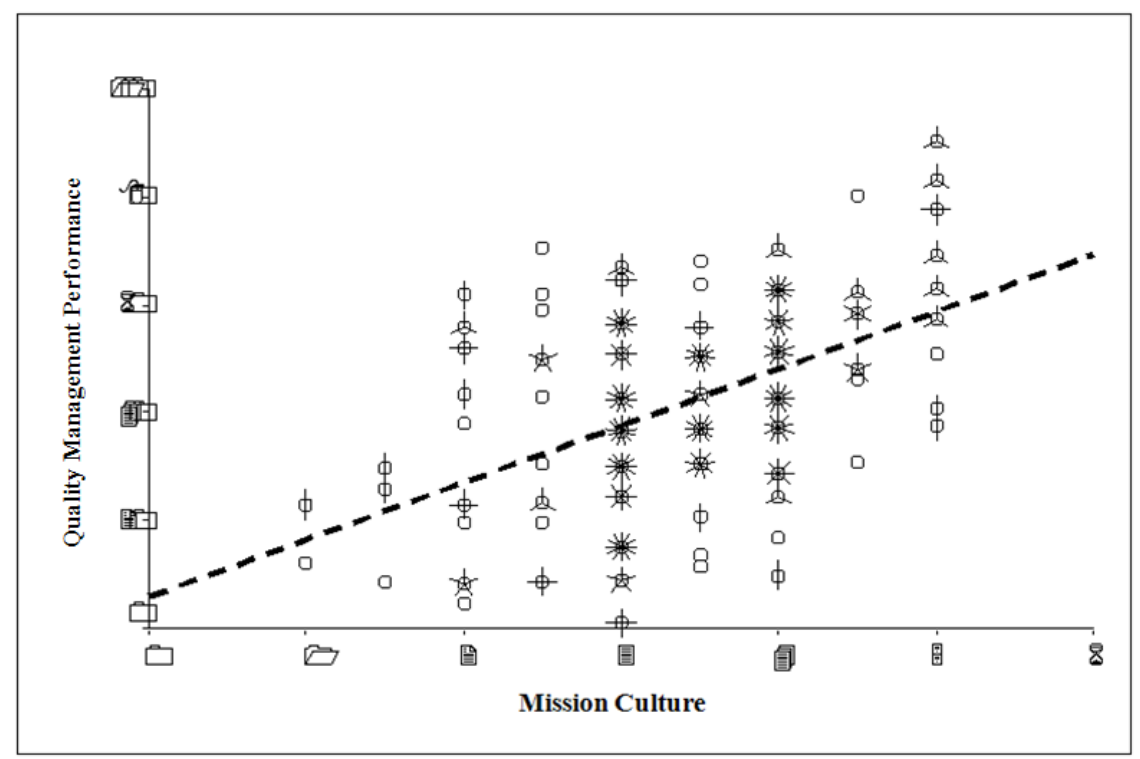

Figure 4. Scatter plot and regression line based on the EFQM model of excellence against mission culture

2.6.4 There Is a Relationship between Bureaucratic Culture and Organizational Excellency Performance Based on EFQM Model

$\mathbf{H}_{0}$ : There is no relationship between bureaucratic culture and organizational excellency performance based on EFQM model.

$\mathbf{H}_{1}$ : There is a relationship between bureaucratic culture and organizational excellency performance based on EFQM model.

Regarding the fact that the levels of significance were significantly less than $0 / 05$ in both cases, therefore, the hypothesis $\mathrm{H}_{0}$ is rejected and this means that there is a significant relationship between bureaucratic culture and the EFQM excellence model. Kendall and Spearman correlation coefficients are calculated as 0.337 and 0.264 between two variables respectively. These points are also reliable regarding the scatter plot in the figure.

Table 6. Correlation test between bureaucratic culture and organizational excellency performance based on EFQM model

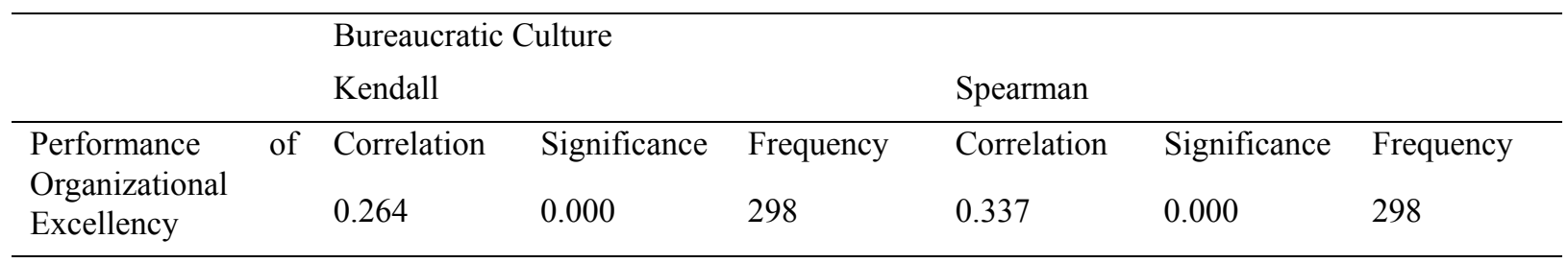




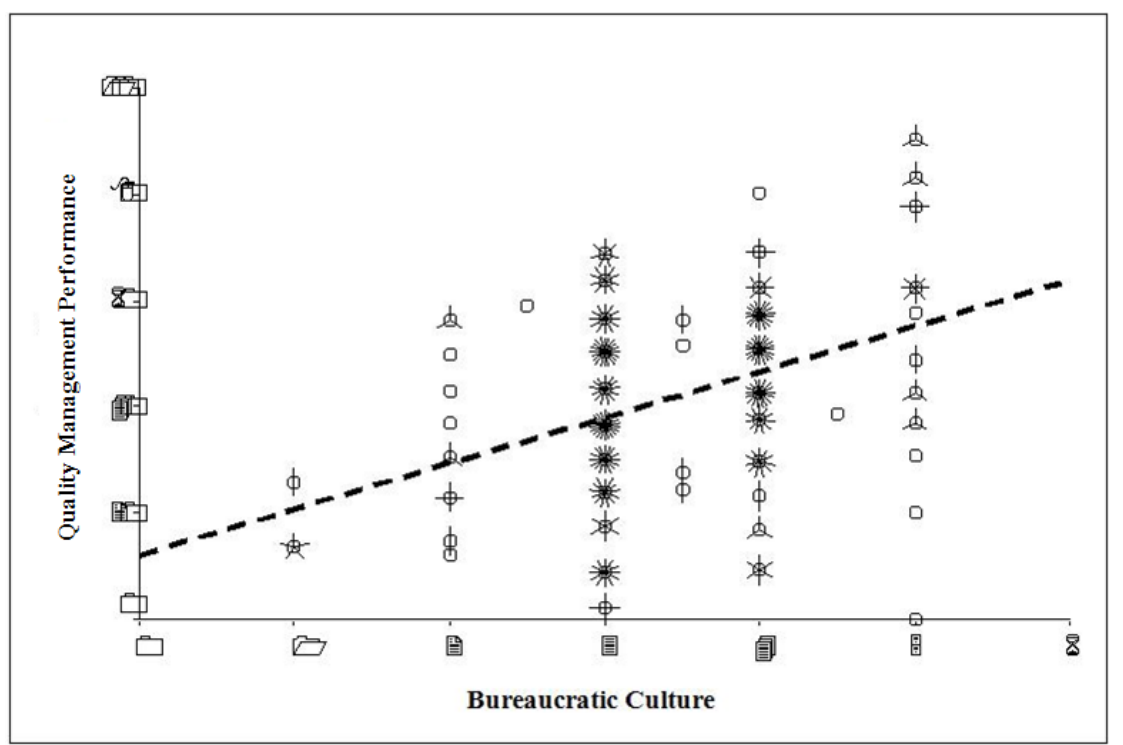

Figure 5. Scatter plot and regression line based on the EFQM model of excellence against bureaucratic culture

\subsection{Organizations Compartment}

2.7.1 There Is a Relationship between Organizational Culture and Organizational Excellency Performance Based on EFQM Model in Productive and Basic Organizations

$\mathbf{H}_{0}$ : There is no relationship between organizational culture and organizational excellency performance based on EFQM model in productive and basic organizations.

$\mathbf{H}_{1}$ : There is a relationship between organizational culture and organizational excellency performance based on EFQM model in productive and basic organizations.

Regarding the fact that the levels of significance of coefficient test were significantly equal to 0.000 (less than 0.05 ) in both cases, therefore, the hypothesis $\mathrm{H}_{0}$ is rejected and this means that there is a significant relationship between the two above variables in basic and productive organizations. These points are also reliable regarding the scatter plot in the figure.

Table 7. The relationship between organizational culture and organizational excellency performance based on EFQM model in productive and basic organizations

\begin{tabular}{lllllll}
\hline \multicolumn{5}{l}{ Performance of Organization Excellency Based on EFQM } \\
& Kendall & \multicolumn{5}{c}{ Spearman } \\
\hline Organization & Correlation & Significance & Frequency & Correlation & Significance & Frequency \\
Culture & 0.459 & 0.000 & 173 & 0.569 & 0.000 & 173 \\
\hline
\end{tabular}




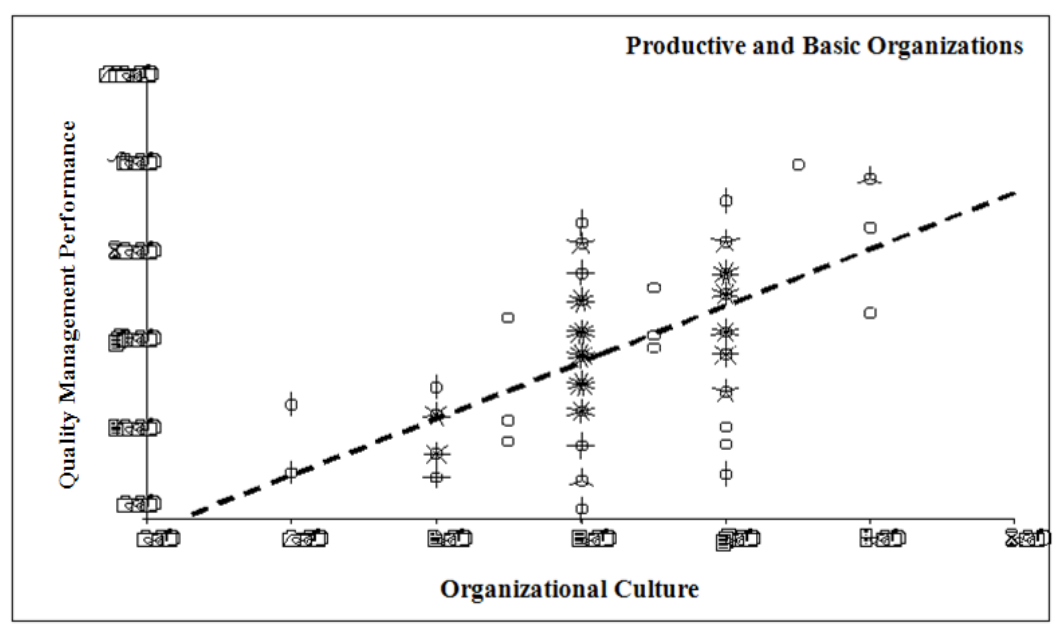

Figure 6. Scatter plot and regression line based on the EFQM model of excellence against organizational culture

2.7.2 There Is a Relationship between Organizational Culture and Organizational Excellency Performance Based on EFQM Model in Educational, Cultural and Research Organizations

$\mathbf{H}_{0}$ : There is no relationship between organizational culture and organizational excellency performance based on EFQM model in educational, cultural and research organizations.

$\mathbf{H}_{1}$ : There is a relationship between organizational culture and organizational excellency performance based on EFQM model in educational, cultural and research organizations.

Regarding the fact that the levels of significance of coefficient test were significantly equal 0.000 (less than 0.05 ) in both cases, therefore, the hypothesis $\mathrm{H}_{0}$ is rejected and this means that there is a significant relationship between the two above variables in educational, cultural and research organizations. These points are also reliable regarding the scatter plot in the figure.

Table 8. The relationship between organizational culture and organizational excellency performance based on EFQM model in educational, cultural and research organizations

Performance of Organization Excellency Based on EFQM

\begin{tabular}{lllllll} 
& Kendall & \multicolumn{3}{c}{ Spearman } \\
\hline Organization & Correlation & Significance & Frequency & Correlation & Significance & Frequency \\
Culture & 0.439 & 0.000 & 125 & 0.560 & 0.000 & 125 \\
\hline
\end{tabular}



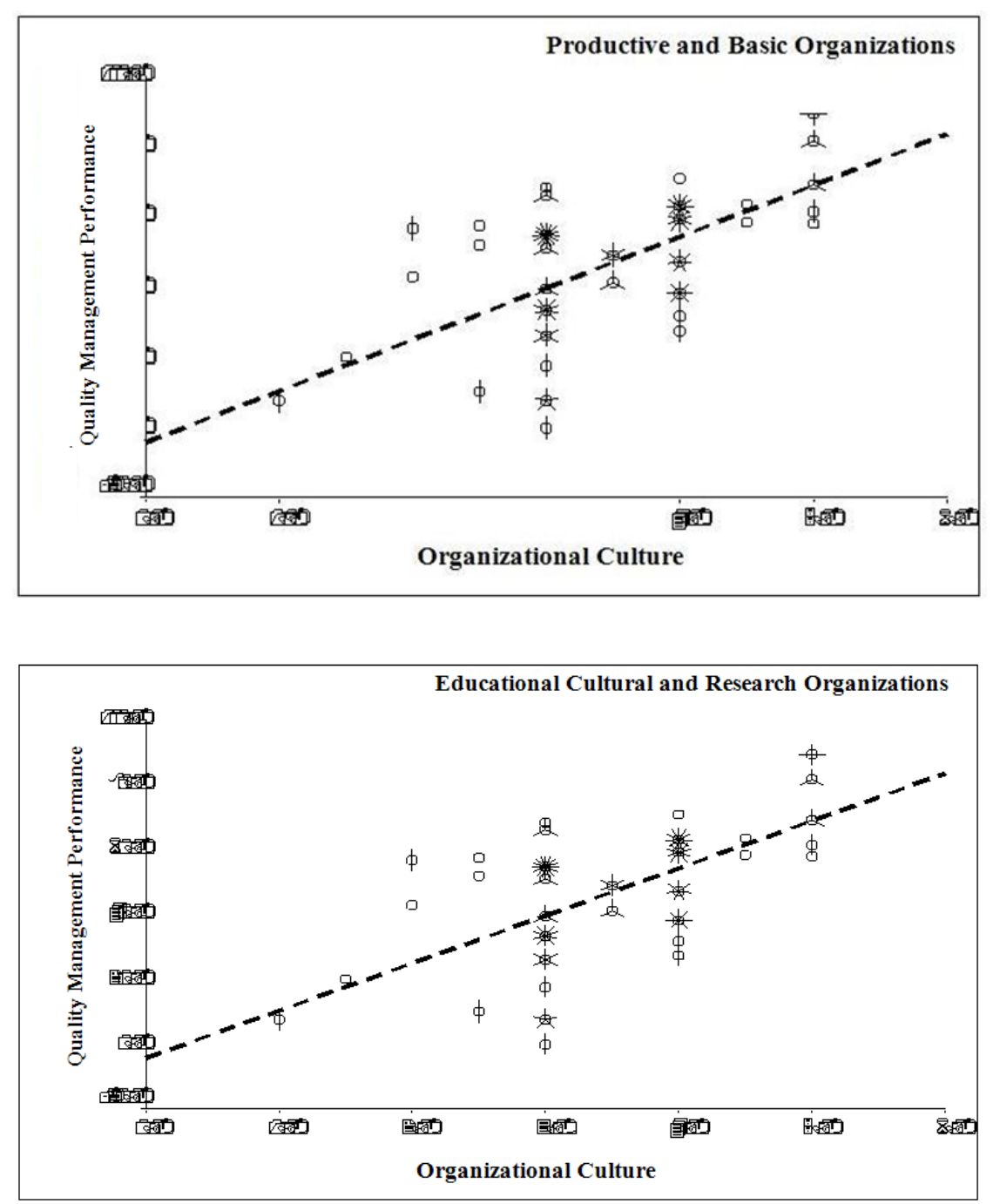

Figure 7. Scatter plot and regression line based on the EFQM model of excellence against organizational culture

2.7.3 Underlying Distribution of Each of the Main Research Variables Is Same in Productive and Basic Organizations and Educational Cultural and Research Organizations

Mann-Vitni Test

$\mathbf{H}_{\mathbf{0}}$ : The underlying distribution of each of the main research variables is same in the two types of organizations.

$\mathbf{H}_{1}$ : The underlying distribution of each of the main research variables is not same in the two types of organizations.

Regarding the fact that the levels of significance of Mann-Vitni (Sig) test were significantly equal 0.000 (less than 0.05) in both cases, therefore, the hypothesis $\mathrm{H}_{0}$ is rejected and this means that the distribution of each one of the variables is not the same in two types of organizations. Regarding the average of ranks, it is specified that the opinions of respondents in educational, cultural and research organizations are higher than the opinions of respondents in basic and productive organizations about both variables. 
Table 9. Comparison of the distribution of each one of the research main variables in both types of organizations

\begin{tabular}{|c|c|c|c|c|}
\hline & $\begin{array}{l}\text { Type of } \\
\text { Organization }\end{array}$ & Frequency & Average of Ranks & Sum of Ranks \\
\hline \multirow{4}{*}{$\begin{array}{l}\text { Organization } \\
\text { Culture }\end{array}$} & $\begin{array}{l}\text { Productive and } \\
\text { Basic }\end{array}$ & 173 & 137.73 & 23828.00 \\
\hline & $\begin{array}{l}\text { Education, Culture } \\
\text { and Research }\end{array}$ & 125 & 165.78 & 20723.00 \\
\hline & Total & 298 & & \\
\hline & $\mathrm{U}=8777.0$ & $\mathrm{~W}=23828.0$ & $Z=-2.955$ & $\mathrm{Sig}=0.003$ \\
\hline \multirow{4}{*}{$\begin{array}{l}\text { Performance of } \\
\text { Organization } \\
\text { Excellency based } \\
\text { on EFQM model }\end{array}$} & $\begin{array}{l}\text { Productive and } \\
\text { Basic }\end{array}$ & 177 & 136.64 & 24184.50 \\
\hline & $\begin{array}{l}\text { Education, Culture } \\
\text { and Research }\end{array}$ & 134 & 181.58 & 24331.50 \\
\hline & Total & 311 & & \\
\hline & $\mathrm{U}=8431.5$ & $\mathrm{~W}=24184.5$ & $Z=-4.365$ & Sig $=0.000$ \\
\hline
\end{tabular}

\section{Analysis and Interpretation}

Culture determines the boundaries of organization which means it separates the organizations. On the other hand, a sense of identity can be injected into the body of organization members and causes that occurs a commitment in people to something that is more than personal interests. In fact, culture causes a stable and sustainable social system. Culture socially considered as a label that can connect components of organization through proper standards "in relation to what members say or do". Finally, culture is a control factor that shapes the attitudes and behaviors of employees. (Robbins, 2010)

Deeper understanding of cultural issues in groups and organizations to find out what is going on there and to determine and identify what may be a priority for leaders and managers is essential. Organizational cultures are established partly by the leaders to a very large extent and one of the most decisive functions of leadership is to establish a culture and sometimes even the destruction of culture (Schein, 2010).

The importance of organizational culture and its impact on organizational performance and life is widely known. Through this thread, alive and dynamic worldwide organizations have achieved unique positions (Kharazmi, 1992).

Organizational culture includes the delicate, subtle forces and somewhat unaware of the work form. Culture, which will greatly resist against change, can be a strength or weakness for the company. Culture can be the reason for the strengths or weaknesses in every unit with important organizational circle (Fred, 2012).

Ali Ahmadi, et al. (2004) believe since culture affects the determination of goals, and strategies of individual behavior and organizational performance, if managers seek to change the productivity and organizational performance, they should pay attention to the forming factors in organizational culture and their changes.

The development and growth of the transcendental communities is a phenomenon that its necessity has been felt today than at any other time in developed countries. Also, developing countries have been realized the importance of the characteristics of transcendental society and its role in accelerating economic progress. In addition, they have introduced and applied organizational excellence models in various industrial and service sectors. With a glimpse at the EFQM models in Europe, we realized that the close relationship between the above models with the degree of economic development and developed countries. These countries believe that transcendent society is admirable to establish and create transcendent organizations (Jelodari, 2004).

To study the vision of the mission, the objectives and critical success factors and, if necessary, changing their structure seems to be essential in order to meet the new requirements of the organization and its internal and external customers. The identification and the assessment of the performance of all processes and staff development activities seem highly necessary till determination of the level of their development. These measures form a new framework for organizational excellence (Mortazavi, 1994).

The Improvement of performance of companies is much discussed in the world. By the increasing number of available models, special care must be taken to approaches that have the most attractive return of investment. 
Over the past decade, a dramatic increase has been occurred in the global competition scene due to technological changes and increasing diversity of products which have been made to improve the performance and strategy as a competitive tool in many organizations around the world. Today, organizations use the repeated measure, control, process improvement and business excellence in order to maintain their competitive advantage of this improvement in performance assessment (Wongrassamee, 2003), (Nawaser, et al. 2011).

Moorhead and Griffin (2011) are of the opinion that organizational cultures are different. Different cultures can differently affect the performance of organizations.

Alwani and Riahi (2003) believe that, nowadays, organizations should be better than yesterday and the attachment to the present status is the most fatal organizational injury in our age. If we accept that there is always room for improvement and progress and it is always possible to achieve best practice methods and techniques, we will work hard every day to have a position better than yesterday.

Furthermore, the presence of a significant relationship in the sub-hypotheses was confirmed although there was no research similar to this study to enable us to compare the results. But, it is suffice to relay on the thinkers' evidence and arguments in this regard as follows:

\subsection{First Hypothesis}

The statistical calculations indicate that there is a relationship between participative culture and organizational excellency performance based on EFQM model.

Excelled organizations manage and improve all levels of their human resource potential in the individual, team and organizational levels and benefit from them. They promote justice and equality and empower their employees and make participation in the affairs. These organizations support their employees to do so. They encourage and praise their personnel to communicate with them which encourage and develop the skills and commitment. They have to use their knowledge for the benefit of the organization (www.inqa.org).

Prominent organizations have leaders that have a clear orientation for the organization and are spreading it. To do so, they motivate managers of the organization and inspire their employees as well. They establish values, ethics, and culture and governance structure in such a way to bring a unique identity and attractiveness for interested parties of the organization. The leaders of these organizations, at all levels, continuously encourage people towards the excellent condition and to do this, they are the behavior and performance patterns for the others (www.iranEFQM.com).

Mamizadeh (1997) believes that the adoption of a strategy depends on the change or transformation within the organization with the cultural patterns that govern the organization.

Monavarian and Bakhtaei (2005) are of opinion that organizations shared a vision of the future status and it expresses a fundamental value that connects thoughts and hearts of human resources and it specifies the direction at the same time. These organizations develop employees' skills in order to meet the needs and continually remain competitive. The effective organizations empower their personnel and establish organization based on working groups and develop human resource capabilities at all levels. The members of the organization commit to their work and feel that their members are as parts of a body. People, at all levels, feel involved in decisions and these decisions affect their work and their work is directly linked to organizational goals.

Seyyed Javadein (2004) states that organizational culture connect the components within the organization and reflect the interactions and relationships, behaviors, practices of members of the organization and on the other hand, it is a factor and index of separation of an organization from other organizations.

The excellent organizations have realized the increasing importance of intellectual capital in favor of their employees in finding their knowledge to upgrade their benefit. These organizations are looking for rewarding their employees in a way to encourage the commitment to organization in them. These organizations maximize personnel's potentials by promoting organizational values, culture and trust, honesty and capable staff. The ideas of improvement of the organization will be established and performed by creating and expanding the space for participation.

The advantages of applying this concept for the organization are:

-Create a sense of belonging to the organization's goals and objectives

- Committed, loyal and motivated labor

-Highly valuable intellectual capital

-Actualization of employees' potentialities (www.iranEFQM.com). 
Denison, (1990) in an analysis of the financial performance of over 2000 companies, showed that those who have a culture of high interest and high participation had substantially higher performance than those companies that failed attachment and an appropriate contribution to provide employees (Mahdad, 2002).

\subsection{Second Hypothesis}

The statistical calculations indicate that there is a relationship between flexible culture and organizational excellency performance based on EFQM model.

In the present changing world, excellent organizations are always and rapidly agile, flexible and are responsive to the changing needs and expectations of stakeholders. Transcendent organizations measure and predict the needs and expectations of its stakeholders to observe the experiences and perceptions and review the performance other organizations. In these organizations, information about current and future stakeholders are collected in order to determine and review deployments, policies, strategies, goals, objectives, indicators and short-term, medium term and long term planning. This information can achieve a balanced set of results expected by stakeholders.

Ghasemi, (2001) believes that the cultural norms and beliefs in the organization has been approved and are being strengthened in order to identify and interpret the present needs and demands can be found in the environment to act accordingly with the appropriate response. Such organizations are able to react quickly against new needs and change their structures, performance and to take on new behaviors.

Fred R. (2012) argues that organizational culture is established by patterns of behavior that occur in an organization, because the organization gradually learns to solve external problems, internal adaptations and how to integrate activities. Those models that work well have earned a reputation as a true and can be taught to members of the organization to provide them to think and feel from the same angle and in the same format.

Mamizadeh, (1997) believes the acceptance of a strategy to change or transformation within the organization depends on coordination with the cultural patterns that govern the organization. The rate of success of a change, transformation and conflict between depth and breadth of its strategy has an inverse relationship with organizational culture. It means that if the strategies of the evolution or organizational culture are contrary with much of the depth and reduced the likelihood of its success. On the other hand, if the change had little depth and breadth of strategy and its organizations have a little contradiction with culture, the resistance against it will be less, and consequently the success rate will be high. In the middle level, if the change had little of the depth and breadth, but its contrast to the culture and conflict is high or if it contrast the organizational culture a little, but has a lot of depth and extent, the rate of resistance and its probability of success will be moderate.

Prominent organizations are continuously learning from performance results and their or the other activities. They are constantly modeling and optimizing from inside and outside of the organization.

\subsection{Third Hypothesis}

The statistical calculations indicate that there is a relationship between mission culture and organizational excellency performance based on EFQM model.

Monavarian and Bakhtaei (2005) believe that perhaps the most important feature of organizational culture is its mission. Those organizations that do not know how is the existing situation?, often go astray. Successful organizations have a clear understanding of goals and direction so that they define the organizational goals and strategic objectives and the vision of the organization chart.

Jelodari (2004) believes that leaders create mission, vision, values and ethics of their organization and they are pre-eminent cultural patterns in organizations.

\subsection{Fourth Hypothesis}

The statistical calculations indicate that there is a relationship between bureaucratic culture and organizational excellency performance based on EFQM model.

According Monavarianand and Bakhtaei (2005), organizations that are well integrated are difficult to change. The inner integration can be of great advantage.

James Collins and Jerry Peres, after six years of research and compare 18 firms that had long standing success and 18 companies that were not very successful, concluded that culture is the most important determinant of success means the culture where employees and senior managers are in tune with a strong vision of the future of the company. These two authors found that successful companies have a "main or central idea" to celebrate their special values and to determine employee's behavior on the same basis (Daft, 2009). 


\section{Research Limitations}

Man is a creature that has a complex behavior as he may not and cannot state the reality in appropriate situations. Due to this reason; research in humanities is faced with problems. Just like other researches, there were restrictions on the quantity and quality of data which were influential and effective. Limitations of the study were:

- Carried out research on the relationship between organizational culture and organizational excellency performance was very few due to the new topic.

- Lack of cooperation from organizations and personnel of the organizations during data collection phase due to difficulties in collecting the questionnaires. In addition, reluctance to answer some of the subjects regarding culture disbelief in accepting the effectiveness of such researches in this field.

- Using the questionnaire as a measure of research has its own limitations.

\section{Research Suggestions}

* According to the obtained results of the statistical calculations of the impact of organizational culture on organizational excellency performance, it is suggested that executives of government agencies should attempt to establish a proper culture in organization to achieve continuous improvement easily.

* Regarding the obtained results, it is suggested that managers should make effort to introduce and institutionalize the organization's mission and aims.

* Considering the obtained results, it is suggested that managers should make use of all hidden human resources properly and try their best to establish participatory system.

\section{References}

Ali ahmadi et al. (2004). Understanding and Management of Organizational Culture. Towlide Danesh (1st ed.). Tehran, Iran.

Alwani, S., \& Riahi, B. (2003). Measuring Service Quality in the Public Sector. Industrial Research and Training Center of Iran (1st ed.). Tehran, Iran.

Bagherizadeh, S. (1996). Organizational Culture in the Field of Organizational Development. Tadbir, a Monthly Magazine on Management (Vol. 7, No.63). Tehran, Iran.

Daft, R. L. (2009). Organization Theory and Design (10th ed.). South-Western College.

David, F. R. (2012). Strategic Management, Prentice Hall (14th ed.).

Eskildsen, J., Kristensen, K., \& Juhl, H. (2002). Trends in EFQM criterion weights; the case of Denmark 1998-2001, Measuring Business Excellence. http://dx.doi.org/10.1108/13683040210431437

Gerami, M., \& Noralizadeh, H. (2006). Organizational Excellence, Ahar (1st ed.). Tehran, Iran.

Ghasemi, S. (2001). Transformation of Organizational Culture and Control Strategies. Tadbir, a Monthly Magazine on Management (Vol. 12, No.115). Tehran, Iran.

Ghobadian, A., \& Woo, H. S. (1996). Characteristics, benefits and shortcomings of four major quality awards. International Journal of Quality \& Reliability Management. http://dx.doi.org/10.1108/02656719610109999

Griffin, R., \& Moorhead, G. (2011). Organizational Behavior. South-Western College (10th ed.).

Jafari Ghoshchi, B. (2005). Management Development Place in Organization Excellence. Tadbir, a Monthly Magazine on Management (Vol. 16, No. 162). Tehran, Iran.

Jahanshahi, A. A., Rezaei, M., Nawaser, K., Ranjbar V., \& Bairagi, B. K. (2012). Analyzing the effects of electronic commerce on organizational performance: Evidence from small and medium enterprise. African Journal of Business Management, 6.

Jelodari, B. (2004). Organizational Excellence. Ney (1st ed.). Tehran, Iran.

Kharazmi, S. (1992). Culture of Organization. Tadbir, a Monthly Magazine on Management (Vol. 3, No. 22). Tehran, Iran.

Mahdad, A. (2002). Organizational and Industrial Psychology. Jangal. Tehran, Iran.

Mamizadeh, J. (1997). Culture and Infrastructure of the Organization. Tadbir, a Monthly Magazine on Management (Vol. 7, No. 61). Tehran, Iran. 
Monavarian, A., \& Bakhtaei, A. (2005). Understanding of Organizational Culture based on Denison Model. 4th International Conference of Management. Tehran, Iran.

Mortazavi, M. (1994). Study of Organizational Culture of Agriculture Ministry, Master thesis. Tehran University.

Moullin, M. (2004). Eight Essentials of Performance Measurement. International Journal of Health care Quality Assurance, 17(13).

Najmi, M., \& Hosseini, S. (2006). EFQM Excellence Model, From Idea to Execution. Ronas (6th ed.). Tehran, Iran.

Nawaser, K., Khaksar, S. M. S., Shaksian, F., \& Jahanshahi, A. A. (2011). Motivational and Legal Barriers of Entrepreneurship Development. International Journal of Business and Management, 6(11).

Robbins, S. P. (2010). Organizational behaviour. Prentice-Hall (14th ed.).

Schein, E. H. (2010). Organizational Culture and Leadership. Jossey-Bass (4th ed.).

Seyyed Javadein, S. (2004). Management and Organization Theories. Negahe danesh (1st ed.). Tehran, Iran.

Wongrassamee, S. (2003). Performance Measurement Tools: the Balanced Scorecard and the EFQM Excellence Model. Measuring Business Excellence Journal, 7(1).

Zarei, M. H. (1998). The Role of Organizational Culture in Productivity Increase, Zamineh Journal. Kosar economic organization (Vol. 7, No. 64 \& 65). Tehran, Iran.

\section{Copyrights}

Copyright for this article is retained by the author(s), with first publication rights granted to the journal.

This is an open-access article distributed under the terms and conditions of the Creative Commons Attribution license (http://creativecommons.org/licenses/by/3.0/). 